\title{
LEFTWARD MOVEMENT WITH DISCONTINUOUS APPOSITIVE CONSTRUCTIONS*
}

\author{
TANJA MILIĆEV-NATAŠA MILIĆEVIĆ \\ Department of English, Faculty of Philosophy \\ University of Novi Sad \\ Dr. Zorana Đinđića 2 \\ 21000 Novi Sad \\ Serbia \\ natasa.milicevic459@gmail.com; tanjamilicev@yahoo.com
}

\begin{abstract}
A rather standard generalization regarding both clausal and nominal appositives to noun phrases is that the appositive element needs to be right adjacent to its antecedent/anchor (cf. Potts 2003). The exceptions to the adjacency requirement are usually restricted to the cases of extraposition (cf. de Vries 2002 for Dutch; Cinque 2006 for Italian). In some languages, however, such as Serbian or Old English, it is possible to split the antecedent and the appositive without resorting to extraposition. Our claim is that in such cases the observed discontinuity is the result of the leftward movement of the antecedent to a higher position in the clause. We discuss the interpretative and syntactic restrictions on this operation, basing our conclusions on the data from Serbian and Old English. We show that the leftward movement account of this phenomenon is not only the most optimal one, but provides a strong argument in favour of treating appositions as specifying conjuncts, as proposed by de Vries (2002; 2006), rather than noun phrase adjuncts.
\end{abstract}

Keywords: discontinuous appositives, leftward movement, coordination

\section{Introduction}

There have been various views of the syntactic status of appositions to nominal projections such as those in (1).

* An earlier version of this paper was presented at the SinFonIJA 4 organized by the Research Institute for Linguistics of the Hungarian Academy of Sciences, Budapest. We are indebted to the participants of the conference as well as to the anonymous reviewers whose comments greatly contributed to the final shape of this paper.

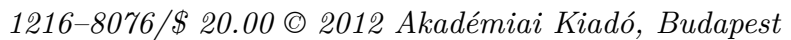


(1) (a) She took my daughter, a renowned doctor, with her.

(b) She took my daughter, Mary, to her son's new school.

Their scopal independence and non-restrictive meaning have been the main motives behind the accounts of appositive expressions as adjoined to the root clause (Ross 1967; Emonds 1979; McCawley 1982). However, the condition of their right-adjacency to the antecedent noun phrase discussed in (Potts 2003) speaks in favour of treating them as part of a lower-level (non-clausal) constituent.

(2) (a) *She took my daughter with her, a renowned doctor.

(b) *She took my daughter to her son's new school, Mary.

Assuming that other nominal appositives, such as appositive relative clauses, share most of the properties of their NP/DP counterparts, and that both, quite plausibly, require a unified syntactic account, ${ }^{1}$ we gain more circumstantial evidence for the NP (or NP related) constituent approach.

As shown in (3), the adjacency condition holds for appositive relatives, too.

(3) (a) * She took my daughter with her, who is a renowned doctor.

(b) * She took my daughter to the new school, whose name is Mary.

Also, in V2 languages we find a strong piece of evidence for analysing appositive relatives as subordinate clauses within a noun phrase. As subordinate clauses are exclusively verb-final, viewing them as main-clause conjuncts is clearly unsupported.

(4) Annie, die viool spelt, heeft een nieuwe strijkstok gekocht.

Annie who violin plays has a new bow bought

'Annie, who plays the violin, bought a new bow.' (Dutch; de Vries 2006, 234)

Regarding the base-generation of appositive expressions then, we take it that they are introduced into the structure to make a non-clausal constituent together with their nominal antecedent. With this much in mind, we turn to the cases of discontinuous appositions in other languages, such as those in (5).

${ }^{1}$ That appositive relatives could be analysed analogously with (non-restrictive) appositions has been proposed before (cf. de Vries 2006, 230). 
(5) (a) pa æfter pam pe he hit him gesæd hæfde, he cwæð se man then after that he it him said had he said the man pa gyt pas word: then yet these words 'after he had said it to him, he, the man, then said these words:'

(Old English [cogregdC,GDPref20.291.1.4303])

(b) Marija sutra, profesorica latinskog, odlazi u penziju.

Mary tomorrow professor of-Latin goes to retirement

'Mary, professor of Latin, retires tomorrow.'

(Serbian)

We will argue that the splitting of the antecedent nominal from its appositive in Serbian and Old English is derived through movement. In what follows, we will define the syntactic properties of such movement and the interpretative effects that consistently follow it. Section $\mathbf{2}$ describes the data, drawing the relevant generalisations. The examples in Serbian have been elicited from native speakers, while the Old English facts are taken from the York-Toronto-Helsinki Parsed Corpus of English prose by Taylor et al. (2003). In section 3, we discuss the interpretation of discontinuous appositions. Section 4 presents our proposal for an analysis, which incorporates the appositive structure account of de Vries (2002; 2006). Section 5 concludes the paper.

\section{Discontinuous appositions}

Even in Modern English, there are instances where the adjacency condition on the generation of an appositive does not seem to hold.

(6) (a) Randy, the Texan, makes the best enchiladas.

(b) Randy, however, the Texan, makes the best enchiladas.

Examples like (6b) obligatorily involve the occurrence of the adverbial expressions however, on the other hand, which trigger a kind of contrastive interpretation. More importantly, the situations in English where discourse adverbials disrupt the linear adjacency of the antecedent and the appositive do not involve leftward movement of the antecedent. This is shown by the standard constituency tests, such as clefting or topicalization in (7). 
(7) (a) It is Randy, however, the Texan, who makes the best enchiladas.

(b) Randy, on the other hand, the Texan, I would not recommend.

(c) * Randy, on the other hand, I would not recommend the Texan.

The movement involved in the derivation of the grammatical examples in (7) always takes the entire constituent, and the ungrammaticality of (7c) shows that the appositive is obligatorily its integral part. ${ }^{2}$

Another instance where the appositive does split from its antecedent is given in (8), and is standardly assumed to involve the extraposition of the appositive relative clause. Beyond these cases, present-day English does not allow the derivation of discontinuous appositions.

(8) (a) Only the flower is used, which is not poisonous and is attached to the plant with a very fine stem.

(b) I was talking to Howard the other day, who tells me you want to resign.

The focus of this paper involves the languages and/or instances of the clause-internal movement we saw in (5). Although adverbs can arguably be inserted into the structure parenthetically, as in (5b), this can hardly be the case with intervening verbs. ${ }^{3}$ In Serbian, both subject $(9 \mathrm{a}-\mathrm{b})$ and object antecedent $(9 \mathrm{c}-\mathrm{e})$ can be separated from its appositive, and the intervening material can include elements other than discourse adverbs. The examples below feature an intervening adverbial and a verb.

(9) (a) Marija sutra, profesorica latinskog, odlazi u penziju. Mary tomorrow professor of-Latin goes to retirement 'Mary, professor of Latin, retires tomorrow.'

(b) Marija daje, profesorica latinskog, dobre ocene. Mary gives professor of-Latin good grades 'It is Mary, the professor of Latin, who gives good grades.'

(c) Petar je Mariju nesumnjivo, profesoricu latinskog, video tamo. Peter aux Mary.acc undoubtedly professor.acc of-Latin seen there 'Peter undoubtedly saw Mary, the professor of Latin, there.'

${ }^{2}$ We will disregard the curious placement of discourse adverbs exemplified, which goes beyond the point made here regarding the non-clausal status of apposition.

${ }^{3}$ An anonymous reviewer points out that the intervening adverbs may indeed require a different analysis. However, the interpretative effects we discuss below are systematically the same in all the cases regardless of the category of the intervening material. In addition, the comma intonation sets off the appositive rather than the adverb in (5b) and all similar cases.

Acta Linguistica Hungarica 59, 2012 
(d) Petar je juče Mariju video, profesoricu latinskog, u bioskopu. Peter aux yesterday Mary.acc seen professor.acc of-Latin in cinema 'It was Mary, the professor of Latin, that Peter saw in the cinema yesterday'

(e) Mariju je Petar juče video, profesoricu latinskog, u bioskopu. Mary.acc aux Peter yesterday seen professor.acc of-Latin in cinema 'It was Mary, the professor of Latin, that Peter saw in the cinema yesterday'

In Old English, again, both subject and object splitting is possible, and the same pattern shows up.

(10) (a) ba æfter bam be he hit him gesæd hæfde, he cwæð se man then after that he it him said had he said the man pa gyt pas word: then yet these words 'after he had said it to him, he, the man, then said these words:'

(Old English [cogregdC,GDPref20.291.1.4303])

(b) \& hie ( $m$ ) on pa seamas \& pa ping ðara ura

and them one the seams and the things of-the our wicstowa earfoðlice... gesomnode.

dwelling-place with-difficulty assembled 'and one/people collected (them) the seams and the things from our dwelling place with great difficulty'

(coalex, 30.5.369)

Obviously, as languages with freer word order, Serbian and Old English allow for a greater syntactic mobility also in the case of deriving discontinuous appositions. However, there seem to be constraints on the distribution of the split antecedent. The generalisation in this respect is that in both languages, when the intervening material is referential, this leads to infelicitous results. For Serbian, this is exemplified by (11) and (12).

(11) (a) ${ }^{\#}$ Marija njima/studentima, profesorica latinskog, daje dobre ocene. Mary them/students.dat professor of-Latin gives good grades 'Mary, professor of Latin, gives good grades to them.'

(b) ${ }^{\#}$ Petar je predstavio Mariji studente profesorici

Peter aux introduced Mary.dat students.acc professor.dat

latinskog juče na prijemu.

of-Latin yesterday at reception

'Peter introduced the students to Mary, a teacher of Latin, yesterday at the reception.' 
(12) (a) Mi ti lingvisti to najbolje znamo.

We you.cl.dat.ethical linguists that best know

'We linguists (to-you) know that best.'

(b) ${ }^{\#} \mathrm{Mi}$ ti lingvisti to možemo objasniti.

We you.cl.dat linguists that can explain

'We linguists can explain that to you.'

Although, in principle, an object can move to a position higher than the subject, it cannot cross the subject in the course of the discontinuous subject-apposition derivation, as in (11). Example (12) shows that, although Serbian clitics obligatorily take the second position in a clause, attaching to the first phrase within their intonational phrase (IP) (cf. Bošković 2001; 2004; Progovac 1996; Ćavar-Wilder 1994), argument clitics cannot disrupt the antecedent-apposition sequence. Thus, the example with an ethical-dative clitic in (12a) is perfectly grammatical (as is any auxiliary clitic in that position), while that with an argument clitic (12b) is not. ${ }^{4}$

In Old English, a referential expression, though possible in the higher clausal domain, preceding the high adverb $b a$ 'then', cannot be found in that position if it disrupts the sequence of referential expressions that once constituted a noun + apposition unit (13b).

(13) (a) Pa he hit ba on honda hæfde...

when he it then in hand had

'When he had it in his hands...' (cobede,Bede_4:25.348.4.3497)

(b) * ${ }^{\mathrm{Pa}}$ he hit ba se biscop on honda hæfde...

when he it then the bishop in hands had

When the high adverb is absent, the splitting seems to become more permissive. However, as we have encountered only two cases with a subject antecedent split from the appositive by an object, and none with object antecedents, we believe that this is still a minority pattern, presumably equally infelicitous in Old English as in Serbian.

The above facts clearly indicate that linear non-adjacency between the antecedent and the appositive is allowed only when it in no way affects

${ }^{4}$ Ethical dative in Serbian occurs only on non-argument pronouns and signals familiarity or intimacy. More precisely, in (12a) it modifies the NP 'linguists' indicating familiarity or special connection between linguists and the addressee assumed by the speaker. 
the unambiguous relation between the appositive and the antecedent. We leave it for further research to work out the details of what counts as 'unambiguous relation'. Crucially, no such restriction plays a role with discontinuous appositive constructions derived by extraposition.

\section{The interpretation of discontinuous appositions}

The semantic interpretation of the split antecedent in both languages under consideration is consistent. In Serbian, it always receives focus interpretation. The subject antecedent is interpreted as contrastively focused, while the object antecedent, interestingly, also allows narrow focus interpretation. Thus, two of the relevant examples in (9), repeated here for convenience as (14a-b), are felicitous in a context where Marija is picked from a set of alternatives. Therefore, the implications of (14a) and (14b), respectively, are that no other professor is that generous with grading, and that, of all people, she is the one Peter met.

(14) (a) MARIJA daje, profesorica latinskog, dobre ocene.

Mary gives professor of-Latin good grades

'It is Mary, the professor of Latin, who gives good grades.'

(b) Petar je MARIJU nesumnjivo, profesoricu latinskog, video tamo.

Peter aux Mary.acc undoubtedly professor.acc of-Latin seen there

'Undoubtedly, Peter saw MARY, the professor of Latin, there.'

A sentence like (14a) cannot be felicitously used as an answer to a wh-question. The fronted object in (14b), however, can express new information, as the sentence can provide an answer to a question (Who did Peter meet?). It has been noted that in Slavic certain word orders with fronted objects (most notably, OSV) constitute so-called emotive sentences (cf. Stjepanović 1999 and the references there) where, in addition to providing new information, the focus on the object also serves to emphasize that no other alternatives are to be considered (Peter saw Mary, professor of Latin, and no one else), which is a property of contrastive focus. It is plausible that the same type (or use) of focus is involved in (14b), where the object has undergone relatively short movement out of VP (rather than moved to the clause initial position). In addition, the fronted antecedents bear heavy emphatic stress, being prosodically marked for contrastive focus. 
Non-split appositions, on the other hand, are not associated with one particular interpretation. They can be interpreted both as new information focus and as contrastive focus. ${ }^{5}$

In Old English, the split antecedent needs to be contrastive or switch discourse topic. This is most clearly illustrated in (10a), repeated as (15), where the topic switch is obviously required for disambiguation purposes, and is indicated by means of splitting and fronting the second occurrence of the pronominal he, leaving behind the related appositive expression.

(15) ba æfter pam pe he hit him gesæd hæfde, he сwæð se man

then after that he it him said had he said the man

pa gyt pas word:

then yet these words

'after he had said it to him, he, the man, then said these words:'

(Old English [cogregdC,GDPref20.291.1.4303])

The generalization that emerges is that discontinuous appositions are licensed exclusively by the contrastive focus interpretation, and that topicalization or scrambling are not involved in the type of movement that derives them. ${ }^{6}$ Consequently, if a language makes use of movement to indicate this type of contrastive meaning, this is how they will be derived. Assuming, following Potts (2003), that appositives need to be non-presupposed and non-backgrounded, the requirement that something about the antecedent needs to be discourse novel is not surprising. If topicalization and scrambling are understood as movement of backgrounded, given material, the ban on these types of leftward movement in deriving discontinuous appositions falls out straightforwardly.

\section{A proposed analysis of discontinuous appositions}

\subsection{Adjunction vs. coordination}

As we have shown so far, the syntactic distribution of discontinuous appositions in Serbian and Old English is very similar, as well as the essentially

${ }^{5}$ Of course, it remains to be established what the difference between contrastively focused split and non-split appositions might be.

${ }^{6}$ Scrambling here refers to clause internal reorderings, while topicalisation is the movement to the clause-initial position exclusively. We do not assume crucial interpretative differences between them. 
interpretative effects that accompany it. This calls for a unifying analysis that would allow for a leftward movement of the noun phrase antecedent in both languages. The question is, therefore, what type of a constituent is formed through the base-generation of the apposition, which would, in both languages, further facilitate the extraction of the relevant noun phrase.

In the vast literature on the syntactic status of appositive expressions (whether appositive relative clauses or nominal appositives), the single base-generated constituent approach, which goes back to Jackendoff (1977), seems to have gained a firmer ground than the rootclause conjunction analysis. Among the proponents of the single constituent approach to the generation of nominal appositives (e.g. Sells 1985; Del Gobbo 2003; Potts 2003; de Vries 2002; 2006), there are differences regarding the proposed category of such a constituent. While de Vries proposes a special type of coordination phrase (16a), others argue for a complex DP where the appositive is adjoined to the antecedent or anchor DP (16b). ${ }^{7}$

(16) (a) [CoP DP [ \&: [DP]]]

(b) $[\mathrm{DP}[\mathrm{DP}][\mathrm{DP}]]$

In de Vries's account the head of this special type of coordination is an empty specifying conjunct that introduces an appositive nominal in the complement position, while the antecedent, or the DP that is specified, is in the Spec position of the relevant phrase.

While both approaches capture the fact that the appositive escapes the scope of the antecedent's determiner, as well as the familiar adjacency condition in modern Germanic languages, none can readily facilitate the antecedent split discussed in this paper. A coordination phrase is standardly an island for movement, and DP right-adjunction would block the extraction of the lower DP. However, when we consider the syntax of nominal and coordinating phrases in both languages, the specifying conjunction proposed by de Vries turns out to be an adequate solution to the problem, provided that we allow movement from the first conjunct, the specifier of the conjunction phrase.

${ }^{7}$ It is worth mentioning that Heringa (2011) proposes a clausal structure for the nominal apposition (the second conjunct in (16a)), which is not an issue we are directly concerned with here. 
Conceptually, this move can be justified since the specifying conjunction is not a standard type of coordination. ${ }^{8}$ Whether, and to what extent, it constrains movement is essentially an empirical issue.

Allowing the movement of the first conjunct in this structure is similar to allowing the Left Branch Extraction (LBE). As is well known, Serbian permits the splitting of noun phrases via LBE (cf. Corver 1992; Bošković 2005). Although not common, it would not be surprising either to see the same mechanism at work in the specifying conjunction phrases in some languages.

The splitting of noun phrases by LBE is not an option in Old English. However, we do find support for allowing movement out of the left branch of the specifying conjunction in the Old English syntax of coordination. As shown in (17), this language allows the split of the first conjunct in coordination phrases.

(17) (a) pa se Wisdom pa \& seo Gesceadwisnes pis leoð asungen

when the Wisdom then and the Reason this song sung

hæfdon, pa ongan he eft sprecan

had then began he again speak

'When the Wisdom then and the Reason had sung this song, then he began speaking again.'

(coboeth,Bo:3.9.15.106)

(b) Aristodemus ba $\&$ pæt folc beheoldon pone apostol preo tida dæges Aristodemus then and the people beheld the apostle three hours of-day 'Aristodemus then and the people beheld the apostle three hours of the day.' (cocathom1,ÆCHom_I,_4:214.226.830)

(c) Hys apostolica rærdon and heora æeftergengan manega menn of deaðe his apostles raised and his followers many men of death 'His apostles and his followers raised many men from death.'

(coaelhom,æHom_6:324.1027)

Examples (17a-b) feature a coordination split by an adverb, while (17c) shows a finite verb disrupting the sequence of coordinated phrases. The latter most strongly points to the conclusion that the Old English coordination phrase allows the movement of the first conjunct to the left.

Given that the syntax of noun phrases in the two languages is quite distinct (LBE is an option only in Serbian), and that (16b) cannot successfully capture this difference, and/or serve as the starting point for the derivation of the discontinuous appositions we have seen, we conclude

8 To illustrate the function of the null specifying conjunct, de Vries treats it as a null version of or or namely. 
that, in structural terms, the only plausible "common denominator" of the two languages is (16a).

\subsection{Antecedent movement in Serbian}

In this section we offer a more detailed analysis of the discontinuous appositions in Serbian. In section 4.1, we have concluded that the base generation of nominal appositions involves a special coordinating phrase, in which a specifying noun phrase is a complement to the null specifying conjunct. We also claim that this analysis can be extended to appositive relative clauses in Serbian, since they exhibit the same behaviour regarding the movement and interpretation of the split nominal antecedent.

As concluded in section 3, the motivation for separating the antecedent from the apposition is to be found in the information-structure organization of the clause. Since in Serbian the split is licensed by the antecedent's focus interpretation, we propose that it is moved to a focus phrase in the left periphery of the clause. We follow É. Kiss $(1995 ; 1998)$, and also Stjepanović (1999) for Serbian, in assuming that there are two available focus positions within the functional domain of the clause. Thus, examples in (14) are derived by movement of the antecedent either to the higher focus phrase (FP1), or the lower one (FP2). The relevant derivations are represented in (18). ${ }^{9}$ The difference in the relative ordering of the high adverb nesumnjivo 'undoubtedly' (standardly assumed to attach above TP) with the arguments in (18b) and (18c), helps us determine whether FP1 or FP2 is the landing site of the object antecedent.

(18) (a) $\left[\right.$ TOPP $\left[\right.$ FP1 MARIJA ${ }_{i}\left[\mathrm{TP}\left[\right.\right.$ daje $_{\mathrm{v}}\left[\mathrm{VP}\left[\mathrm{CoP}_{\mathrm{i}}[\& \text { : [profesorica latinskog }]\right]\right]_{\mathrm{k}}$ $\mathrm{t}_{\mathrm{v}}[$ dobre ocene]]]]]]

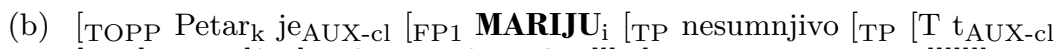
$\left[\mathrm{XP}\left[\mathrm{CoP} \mathrm{t}_{\mathrm{i}}[\&:[\text { profesoricu latinskog }]]\right]_{j}\left[\mathrm{VP}_{\mathrm{k}}\right.\right.$ video $\mathrm{t}_{\mathrm{j}}$ tamo $\left.\left.\left.\left.\left.\left.]\right]\right]\right]\right]\right]\right]$

(c) $\left[\mathrm{TP}\right.$ Nesumnjivo je $\left[\mathrm{TP}\right.$ Petar $_{\mathrm{k}} \mathrm{T}\left[\mathrm{FP} 2\right.$ MARIJU $\mathrm{i}_{\mathrm{i}}$ juče $\left[\mathrm{XP}\left[\mathrm{CoP} \mathrm{t}_{\mathrm{i}}\right.\right.$ $[\&$ : [profesoricu latinskog $]]]_{j}\left[\mathrm{VP}_{\mathrm{k}}\right.$ video $\mathrm{t}_{\mathrm{j}}$ tamo $\left.\left.\left.\left.]\right]\right]\right]\right]$

${ }^{9}$ In $(18 \mathrm{~b}-\mathrm{c})$ the object is scrambled out of the VP. According to native speakers' judgements, this word order is slightly preferred over the non-scrambled one, which is also judged as grammatical. Before determining the reason of this preference, we are, however, not committed to the nature of XP. 
Finally, since de Vries's approach aims at providing a unifying syntactic account of appositions in general, the question that inevitably arises is if the syntax of relative appositives can be accounted for on a par with nominal appositives.

As far as the derivation of the discontinuous appositions in Serbian is concerned, our answer to this question is affirmative. The antecedent's split from the relevant appositive clause is in every respect compatible with the splitting of the antecedent-nominal appositive sequence (19)(20).

(19) (a) MARIJA daje, koja je profesorica latinskog, dobre ocene. Mary gives, who is professor of-Latin good grades 'It is Mary, who is the professor of Latin, that gives good grades.'

(b) Petar je MARIJU nesumnjivo, koja je profesorica

Peter aux Mary.acc undoubtedly who is professor

latinskog, video tamo.

of-Latin seen there

'Undoubtedly, Peter saw MARY, who is the professor of Latin, there.'

(20) (a) Mi ti koji razumemo lingvistiku, to najbolje znamo. ${ }^{10}$ we you.cl.dat.eth who understand linguistics that best know 'We, who understand linguistics, (to-you) know that best.'

(b) *Mi ti koji razumemo lingvistiku, to možemo objasniti. we you.cl.dat who understand linguistics that can explain 'We, who understand linguistcs, can explain that to you.'

The examples in (19) show that the material intervening between the antecedent and the relative appositive is the same as the one we find with split nominal appositives (namely, verbs and adverbs). (20) shows that, in this context too, the interference of another referential expression (in this case, an argument clitic (20b)) is not possible/felicitous.

For the analysis of appositive relatives, we will adopt the structure assumed by de Vries (2006):

(21) $[\mathrm{CoP}$ DP $[\&:[\mathrm{DP}[\mathrm{D} \mathrm{CP}]]]$

${ }^{10}$ In the cases where the appositive immediately follows clitics some of the features of the so-called 'comma intonation' are obliterated (cf. Milićev-Marković to appear). For this reason, we posit a comma only after the appositive, and not before it. 
In the structure proposed, the complement of the null specifying conjunct is a DP whose non-overt head (a null D) introduces a complement $\mathrm{CP}$ - the appositive relative clause. Due to a null external D head, de Vries compares appositive relatives to free relative clauses, describing them as a kind of false free relatives. Their non-restrictive meaning is thus derived from the fact that they are introduced into the specifying structure as a restriction to what we understand to be a null pronominal element.

Without going into the discussion of the internal syntax of the relative clause, we maintain that the movement to the left of the left DP conjunct proceeds in the same fashion as in (18).

\subsection{Antecedent movement in Old English}

As shown earlier, the split antecedent in Old English is necessarily interpreted as a contrastive or switch-discourse topic. Hence, we propose that it moves from the position of the Spec, $\mathrm{CoP}$ to a phrase above the TP projection-a $\Sigma \mathrm{P}$.

Following van Kemenade-Milićev (2011), we assume that $\Sigma \mathrm{P}$ is a high functional projection, reserved for what can best be described as discourse prominent elements, namely subjects (both pronominal and nominal), and object pronouns. Movement to $\Sigma \mathrm{P}$ is commonly diagnosed with respect to the relative positioning of subjects and pronouns with the so-called 'high' adverbs ( $p a$ and pone), which essentially function as discourse adverbs. Raising to the position above these adverbs is, thus, raising to $\Sigma \mathrm{P}$.

The movement to this projection, however, is not topic movement, since discourse prominent elements occur in it even in embedded clauses, which ban topicalisation due to the presence of a complementiser. According to van Kemenade and Miliæev, even if recursion or Split-CP is assumed, we cannot say that topicalisation employs another, lower Topic Phrase for this purpose, since we do not find (non-pronominal) objects or adjuncts before subjects.

Being a projection above the high, discourse, adverbs, which often disrupt the antecedent-appositive string, $\Sigma \mathrm{P}$ is a plausible landing site for contrastive or switch-discourse topics. The derivation of discontinuous nominal appositions would then proceed as in (22).

(22) $\left[\mathrm{CP}\left[\Sigma \mathrm{PP} \mathrm{NP}_{\mathrm{i}}\left[\mathrm{TP}\left[\mathrm{CoP} \mathrm{t}_{\mathrm{i}} \&:[\mathrm{APP}]\right]_{\mathrm{k}}\left[\mathrm{VP} \mathrm{t}_{\mathrm{k}}\right]\right]\right]\right]$ 
Unlike in Serbian, the nature of Old English discontinuous appositive relatives cannot be easily determined. In our view, this does not compromise the general validity of the $\mathrm{CoP}$ approach to the derivation of the appositive relatives. ${ }^{11}$ As noted by Cinque (2006), appositive relatives do not represent a uniform class. Even in a single language, such as Italian, one can differentiate between a more integrated type and a less integrated one, only the former being unable to split from its antecedent. ${ }^{12}$ The type of movement that is employed to this end would probably depend on the internal structure of the second conjunct of the CoP, or the features of the null conjunct itself, which may vary even within one language. All of this, however, remains in the domain of speculation and requires further research.

\section{Conclusion}

In this paper we have presented a less known type of discontinuous appositions, which is found in Serbian and Old English, and is licensed by contrastive topic or focus interpretation. It has been shown that a proper account of such data must invoke a movement of the noun phrase antecedent to the left clausal periphery. Also, given the striking similarities regarding the syntax of discontinuous appositions in both languages, it has been argued that a unifying syntactic approach is in order. Moreover, since the noun phrase syntax in Serbian and Old English is quite distinct, we have shown that such circumstances call for abandoning the DP adjunction analysis of nominal appositions and the adoption of a modified specifying conjunction approach by de Vries, which would allow for the extraction of the first conjunct.

\section{References}

Bošković, Zeljko 2001. On the nature of the syntax-phonology interface: Cliticization and related phenomena. Elsevier, Amsterdam.

Bošković, Zeljko 2004. Clitic placement in South Slavic. In: Journal of Slavic Linguistics $12: 37-90$.

11 The reader is, however, referred to an opposite view by Citko (2008).

12 The more integrated type of appositive relatives is introduced by a $\mathrm{C}$ element che or cui. The non-integrated type of appositives Cinque refers to as il quale appositives.

Acta Linguistica Hungarica 59, 2012 
Bošković, Zeljko 2005. On the locality of the Left Branch Extraction and the structure of NP. In: Studia Linguistica 59:1-45.

Ćavar, Damir-Chris Wilder 1994. Clitic third in Croatian. In: Henk van RiemsdijkLars Hellan (eds): Clitics: Their origin, status and position. Eurotype Working Papers, Theme Group 8, Vol. 6. Also in: Henk van Riemsdijk (ed.) 2010. Eurotype. Vol. 5. Part 1: Clitics in the languages of Europe, 429-68. Mouton de Gruyter, Berlin \& New York.

Cinque, Guglielmo 2006. Two types of appositive. In: University of Venice Working Papers in Linguistics $16: 7-50$.

Citko, Barbara 2008. An argument against assimilating Appositive Relatives to Coordinate Structures. In: Linguistic Inquiry $39: 635-55$.

Corver, Norbert 1992. Left branch extraction. In: Proceedings of NELS $22: 67-84$.

Del Gobbo, Francesca 2003. Appositives at the interface. Doctoral dissertation, The University of California at Irvine.

É. Kiss, Katalin (ed.) 1995. Discourse configurational languages. Oxford University Press, Oxford.

É. Kiss, Katalin 1998. Identificational focus versus information focus. In: Language $74: 245-73$.

Emonds, Joseph 1979. Appositive relatives have no properties. In: Linguistic Inquiry $10: 211-43$.

Heringa, Herman 2011. Appositional constructions. Doctoral dissertation, University of Groningen.

Jackendoff, Ray 1977. $\bar{X}$ syntax: A study in phrase structure. MIT Press, Cambridge MA.

Kemenade, Ans van-Tanja Milićev 2011. Syntax and discourse in Old and Middle English word order. In: Dianne Jonas-John Whitman-Andrew Garret (eds): Grammatical change: Origins, nature, outcomes (DIGS5), 239-55. Oxford University Press, Oxford.

McCawley, James D. 1982. Parentheticals and discontinuous constituent structure. In: Linguistic Inquiry 13:91-106.

Milićev, Tanja-Maja Marković to appear. Clitic placement and the properties of the intonational phrase in Serbian. In: Sabina Halupka-Rešetar-Maja MarkovićTanja Milićev - Nataša Milićević (eds): Selected papers from SinFonIJA 3 (Syntax, Phonology and Language Analysis), Novi Sad, 1-3 October 2010, Cambridge Scholar, Cambridge.

Potts, Christopher 2003. The logic of conventional implicatures. Doctoral dissertation, University of California at Santa Cruz.

Progovac, Ljiljana 1996. Clitics in Serbian/Croatian: Comp as the second position. In: Aaron Halpern - Arnold Zwicky (eds): Approaching second: Second position clitics and related phenomena, 411-28. CSLI Publications, Stanford CA.

Ross, John Robert 1967. Constraints on variables in syntax. Doctoral dissertation, MIT Press.

Sells, Peter 1985. Restrictive and non-restrictive modification. Report \#CSLI-85-28. Stanford University, Stanford CA. 
Stjepanović, Sandra 1999. What do second position cliticization, scrambling, and multiple $w h$-fronting have in common? Doctoral dissertation, University of Connecticut, Storrs.

Taylor, Ann - Anthony Warner - Susan Pintzuk - Frank Beths 2003. The York-TorontoHelsinki parsed corpus of Old English prose. Available through the Oxford Text Archive, http://www.ota.ahds.ac.uk/

Vries, Mark de 2002. The syntax of relativization. LOT, Utrecht.

Vries, Mark de 2006. The syntax of appositive relativization: On specifying coordination, false free relatives, and promotion. In: Linguistic Inquiry $37: 229-70$. 